\title{
Green Public Procurement in Lithuania: Volumes and Possibilities for Environmental Impact Reduction
}

\author{
Renata Dagiliūtė, Kristina Anikanova \\ Department of Environmental Sciences, Vytautas Magnus University, Lithuania
}

crossref $\mathrm{http} / / / \mathrm{dx}$.doi.org/10.5755/j01.erem.58.4.672

(received in September, 2011, accepted in December, 2011)

\begin{abstract}
Green public procurement is a public procurement, which integrates environmental considerations into the public procurement process, and it is considered to be an appropriate tool seeking to reduce negative impacts on the environment. Therefore this paper aims to analyze results of green public procurement implementation in Lithuania over the 2008 - 2010 year period, considering its scope and possibilities for reducing environmental impacts.

It is determined that practical implementation of green public procurement in Lithuania is not smooth and is far from achieving the objectives yet. In 2008 green procurement amounted to $8.3 \%$, in $2009-6.1 \%$, in $2010-5.8 \%$ of the total number of public procurements performed. The biggest share of performed green public procurement is applied for works $(82 \%)$, mainly related to the construction. However, some possibilities to reduce environmental impacts in terms of $\mathrm{CO}_{2}$ have been missed. To compare to the benefit achieved, estimations show that in the case of personal computers, printers and vehicles, $126-150$ tons of $\mathrm{CO}_{2}$ could have been saved additionally per year, if environmental criteria had been applied to $50 \%$ of particular performed procurements. Hence, it is especially important to speed up the development of green public procurement in Lithuania, ensuring not only lowering negative impact on the environment, but also developing the market for environment-friendly goods and services.
\end{abstract}

Keywords: environmental impact reduction, green public procurement.

\section{Introduction}

Green public procurement (GPP) is a public procurement, which integrates environmental considerations in the public procurement process and takes into the consideration the entire life cycle of the product or service (CEC 2008). In addition, it is considered to be appropriate and one of the most effective tools seeking to reduce negative impacts on the environment (EEA 2008, Evans et al. 2010, de Leonardis 2011). It is estimated that applying GPP some countries have reached considerable environmental impact reductions in terms of $\mathrm{CO}_{2}$ (PricewaterhouseCoopers, Significant and Ecofys 2009). De Leonardis (2011) suggests that 60 million tons of $\mathrm{CO}_{2}$ could be saved if all public entities in the EU would require all electricity supplied to be green.
Quite a big share of public expenditure of governmental and public institutions is allocated for public procurements (PP). Governmental procurements account around $17 \%$ of gross domestic product in the EU (http://ec.europa.eu ). Hence, these volumes create high possibilities to perform GPPs and influence the solutions of both environmental impact reductions and sustainable development targets (CEC 2008), as well as the whole economy (Michelsen, de Boer 2009).

Lithuanian government has approved the National Program for the Green Public Procurement Implementation 2007. The aim of this program is to promote GPP and ensure that purchased goods and services would be as environment friendly as possible (National Program for Green Public Procurement 
Implementation 2007). Lithuanian national strategy for sustainable development (NSSD 2009) also aims to reach the level of the leading EU countries in GPP application until 2020. Hence, this is quite a challenging target, as in some countries GPP accounts to $50 \%$ and more of all PP (Evans et al. 2010).

Despite the fact that the concept of GPP was theoretically grounded in 2007, practical aspects of implementation and achieving these goals have not been analyzed in Lithuania. Therefore, the aim of this study is to analyze results of green public procurement implementation in Lithuania over the 2008 - 2010 year period, considering its scope and possibilities for reducing environmental impacts.

The paper is structured as follows. First some methodology issues are presented. In section 3.1 the volumes and main procurement object groups of GPP in Lithuania are presented. Section 3.2 presents some missed possibilities of environmental impact reductions of three product groups. And at the end some conclusions are drawn.

\section{Methods}

Data for the study are obtained from the Public Procurement Office of Lithuania. Possibilities of GPP for mitigation of an impact on the environment are estimated referring to the results of the Study on Integrated Environmental Impact of Implemented Public Procurement (Study on integrated... 2008).

Overall volumes of PP and GPP, structure according procurement object and main products groups, as well as main purchasers are analyzed and presented in the paper.

Estimating a potential for environmental impacts reduction, it was assumed that $50 \%$ of all purchased goods would have been "light green" or "dark green" depending on the environmental criteria applied. "Light green" is considered to be a product with up to 3 environmental criteria applied, "dark green" with 3 and more environmental criteria, mainly related to energy consumption (Study on integrated... 2008). The particular environmental criteria are not specified in the study, as the study is aiming not at the efficiency of different criteria, but at overall environmental impacts mitigation possibilities of GPP.

The potential for environmental impact mitigation of GPP was expressed in greenhouse gases - $\mathrm{CO}_{2}$ amount (on the $\mathrm{CO}_{2}$ calculations and related methodology see more in the Study on Integrated... 2008). The threshold of $50 \%$ was chosen according to the expressed goals to reach the most advanced EU countries in the field of GPP (NSSD 2009), having in mind that GPP amounts to half of all public procurements in some leading countries of the EU (Evans et al. 2010).

\section{Results and Discussion}

\subsection{Trends and volumes of GPP in Lithuania}

Recently the number of public procurement contracts (except the year 2009 due to the economic crisis) is significantly growing in Lithuania. Over the period of 2001 - 2010 the number of public procurements nearly tripled. The financial EU support has significantly increased the number of purchasing institutions which have to follow the Law on Public Procurement (1996). Hence, this has led to the increase in the number of the public procurement contracts, too (Figure 1). The value of performed PP amounted to 10.9 billion of litas in 2010. After the launching of the Green Procurement Policy in 2007 in Lithuania, environmental criteria started to be applied to public procurements. Environmental criteria were applied to 729 processes of PP in 2010 (Figure 1). However, it is noticeable that practical implementation of GPP in Lithuania is not smooth and is far from achieving the foreseen objectives yet. It has been estimated that in the year 2007 GPP accounted to $5 \%$ of all public procurements.

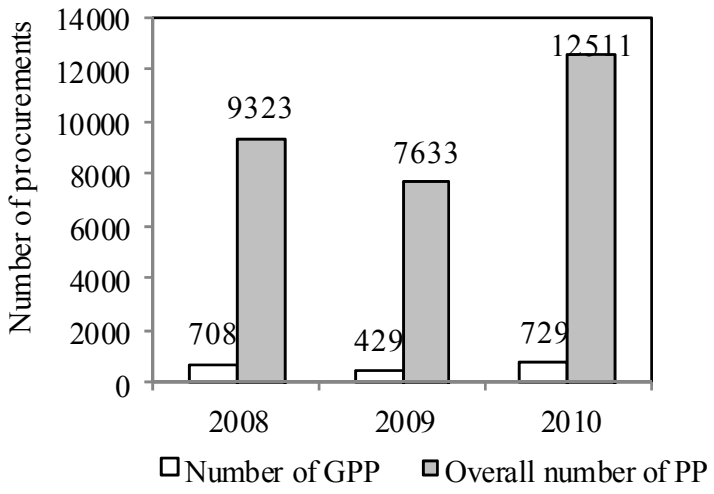

Fig. $1 \quad$ Number of overall and GPP in Lithuania during 2008 - 2010 (Source: Public Procurement Office

After the launching of GPP policy in Lithuania, when more accurate data started to be collected, GPP made up $8.3 \%$ in $2008,6.1 \%$ - in $2009,5.8 \%$ - in 2010 of the total number of public procurements performed. Meanwhile, the strategic objective expressed in the National Program for Green Public Procurement Implementation (2007) is to reach 25\% in Lithuania in 2011. For example, in Nordic countries (Finland, Sweden and Denmark) even in 2005 the environmental criteria were included in $66 \%$ of tender calls (Nissinen et al. 2009).

Then analyzing the value of performed procurement, GPP made up to $18.4 \%$ of the value of all public procurement (1641.1 million LTL) in 2010 (Figure 2). Nevertheless, it is worth mentioning that over the short history of GPP in Lithuania, the monetary value of performed GPP is also decreasing (Figure 2). 


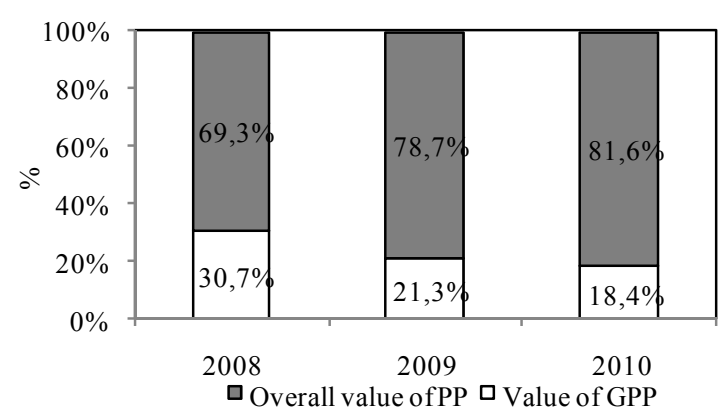

Fig. 2 Structure of performed PP value over 2008 2010 in Lithuania (\%). (Source: Public Procurement Office)

The biggest share of performed GPP is applied to purchased works $(82.1 \%)$, mainly related to the construction (Figures 3, 5). Services accounted to $9.3 \%$ and goods - to $8.6 \%$ of all value of GPP in 2010 (Figure 3). The share of the value of goods and services is on a slightly increasing trend.

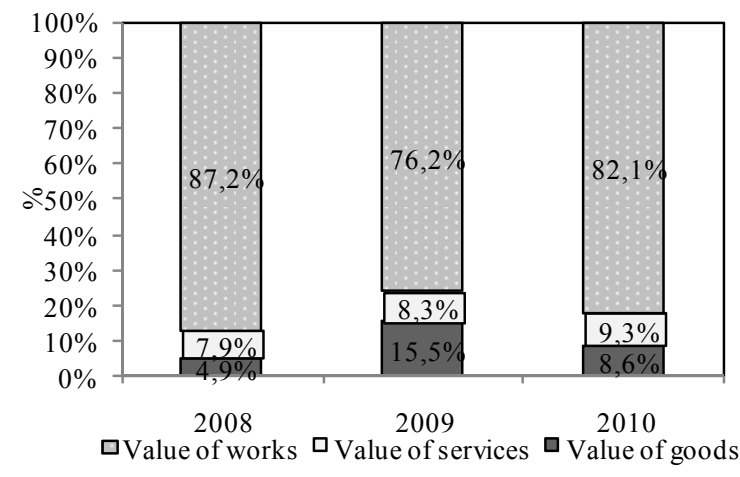

Fig.3 Structure of the GPP value according to the procurement object over 2008 - 2010 (goods, services, works, \%). (Source: Public Procurement Office)

According to the National Program for Green Public Procurement Implementation (2007) governmental organizations have to apply environmental criteria to their procurements. As results show the organizations which must perform GPP performed only 211 GPP in 2009 and this was only $6.1 \%$ of all procurement those organizations had performed during that year (Figure 4). Undoubtedly, it should be positively evaluated that the value of GPP was much higher and amounted to $24 \%$ of overall PP value of organizations which must apply environmental criteria to their PP.

However, rather a low number of GPP could be determined by some lack of political commitment like clear and applicable GPP procedures, particular targets and defined responsibilities.

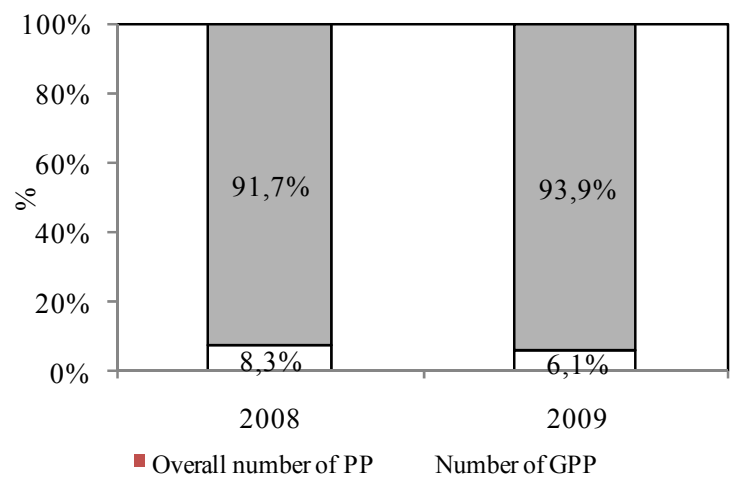

Fig. $4 \quad$ Structure of PP by the institutions that must apply environmental criteria to their procurements over 2008 - 2009 (\%). (Source: Public Procurement Office)

Then analyzing main product and service groups to which environmental criteria were applied most, it is seen that construction works account to more than $80 \%$ of all products and services purchased (Figure 5). This includes motorway construction, road maintenance and repair, school construction and renovation, street construction, etc. Architecture, construction and engineering services made up 2.7\%, agriculture, forestry horticulture, and aquaculture and apiculture services $-3.1 \%$ of all purchased products and services, according their value (Figure 5).

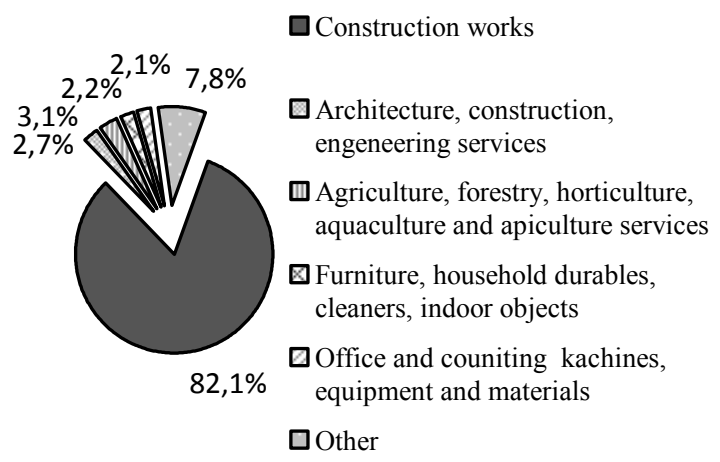

Fig. 5 Main object categories of green procurement in $2010(\%)$

Source: Public Procurement Office

Among the institutions, which have to apply environmental criteria to their procurements, the biggest share of GPP contracts (according to the green procurement value) in 2009 was allocated to the Lithuanian road administration (34\%), public institution "Plačiajuostis internetas" (12\%) and the Municipality of Druskininkai (5\%). State company "Regitra" performed 5\% of all GPP, "Lietuvos geležinkeliai" - $2 \%$, according to their monetary value (Figure 6). This could be associated mostly with the investment in infrastructure and application of environmental criteria for the purchasing construction works and services. 


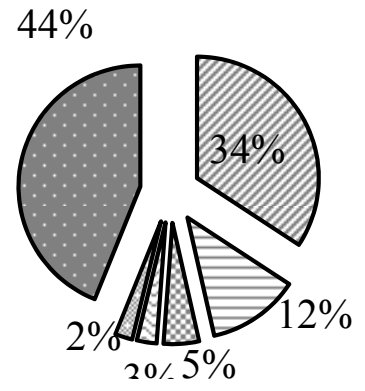

consumption, and environmental pollution over the whole life cycle of products and services. The barriers also include insufficient knowledge on environmental criteria and practical experience on GPP application. Furthermore, not clear responsibilities in GPP, rather unambitious or nonexistent political will and absence of responsibility for environmental impacts during the whole product or service life cycle harden a wider application of GPP to practise.

Nevertheless, it is important to proceed with the foreseen strategic goals, provide relevant information and support GPP specialists (with examples of procurement technical specifications, website, etc.) and business (on investments in green technologies, green markets, possible benefits and possibilities, etc.), spread best practice examples and strengthen political commitment at the national and local level. As de Leonardis (2011) states more mandatory behaviour rather than recommendations are needed in this area. And according to Michelsen and de Boer (2009) very often the cheapest offer overcomes environmental arguments in the purchasing processes, even if purchaser indicated preference to environmental aspects of the product or service in the tender (Nissinen et al. 2009). well as the notions that "green" products are more expensive. Also there is a prevailing lack of information on the benefits and resource
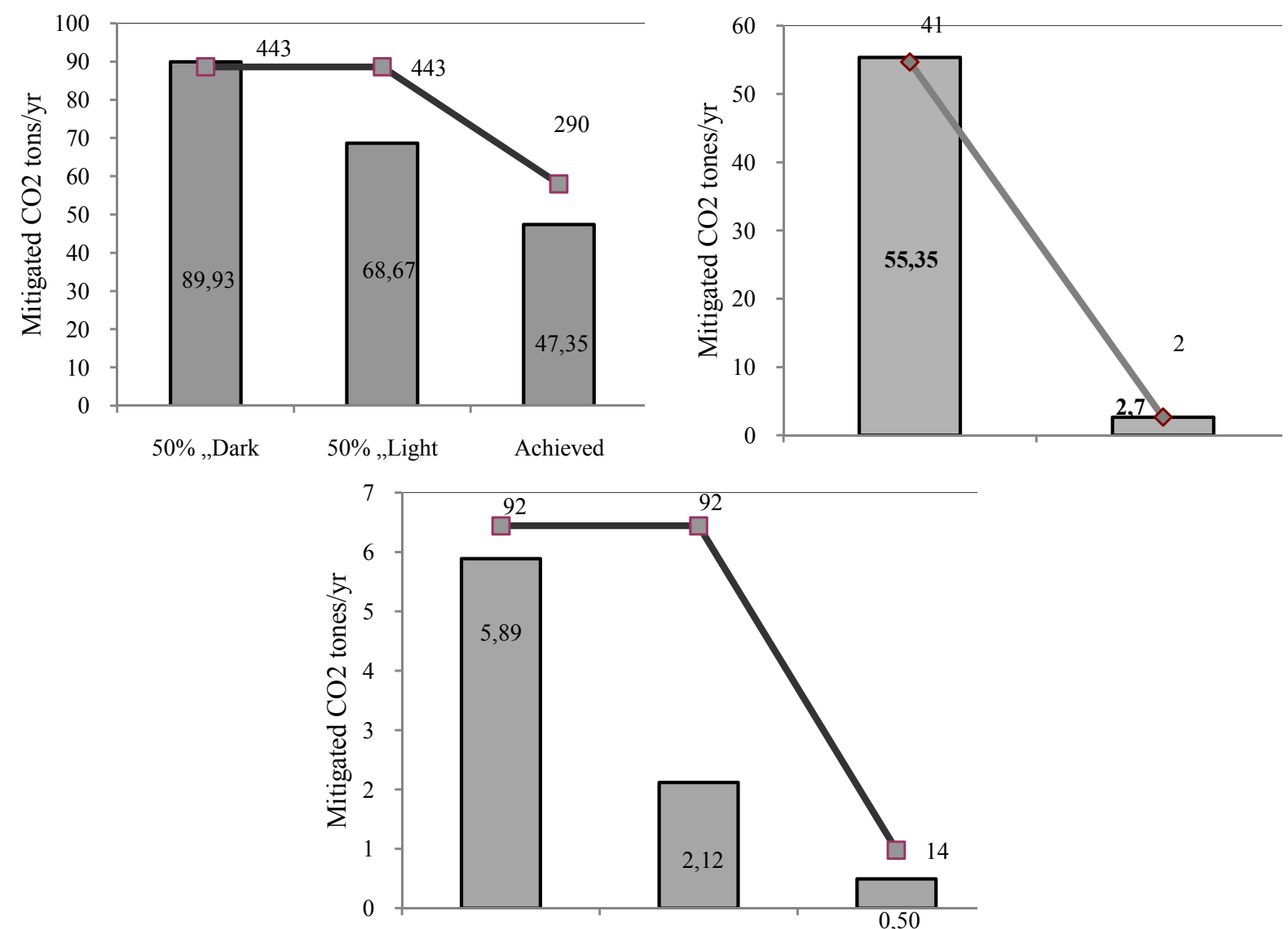

Fig. 7 Achieved and potential benefit of GPP (expressed in reduced $\mathrm{CO}_{2}$ emission in three product groups) Calculations, (based on Study on Integrated..., 2008) 


\subsection{Possibilities of GPP for environmental impact reduction}

Evaluating possibilities of GPP for environmental impact reduction, it has been determined that purchasing the products that meet certain environmental requirements is a useful tool to reach the foreseen goals (Evans et al. 2010). It is estimated that more efficient toilets and taps in public institution buildings could reduce water consumption by 200 million $\mathrm{m}^{3}$ (de Leonardis 2011) and purchasing energy efficient computers could reduce greenhouse emission by around 830 thous. tons of $\mathrm{CO}_{2}$ equivalents in the EU (Nissen et al. 2009).

These possibilities could be employed in Lithuania, too. However, based on already accomplished procurements, the analysis reveals that some possibilities of reducing environmental impacts in terms of $\mathrm{CO}_{2}$ have been missed in a Lithuanian case. To compare to the benefit achieved, our estimations show that in the case of personal computers 2 times more of $\mathrm{CO}_{2}$ could have been saved, in the case of printers - 12 times and in the case of vehicles 20 times more of $\mathrm{CO}_{2}$ could have been saved additionally if environmental criteria had been applied to $50 \%$ of particular performed procurements during the period from the $1^{\text {th }}$ of January to the $1^{\text {th }}$ of October in 2008 (Figure 7). Only then up to 3 environmental criteria would have been applied to the procurement ("light green"), in the case of personal computers 68.6 tons of $\mathrm{CO}_{2}$ would have mitigated per year, in the case of cars - 55.3 tons of $\mathrm{CO}_{2}$, laser printers - 2.1 tons of $\mathrm{CO}_{2}$ per year would have been saved.

If then more than three environmental criteria had been applied ("dark green", 89.9 tons of $\mathrm{CO}_{2}$ emission could have been reduced, in the case of printers -5.9 tons of $\mathrm{CO}_{2}$.

Altogether, if then environmental criteria had been applied to the half of the products in those three groups of goods, depending on the number of environmental criteria applied, 126 - 150 tons of $\mathrm{CO}_{2}$ could have been saved instead of reduction in 50.5 tons mitigated in 2008. This means that compared to the achieved GPP results, additionally at least 75.5 tons of $\mathrm{CO}_{2}$ emission could have been reduced.

Hence, it is especially important to speed up the development of GPP in Lithuania, ensuring not only lowering negative impact on the environment, but also developing the market for environment-friendly goods and services. Provision of appropriate information for business and procurement specialists as well as more clear commitments for purchasing organizations could be beneficial for fosterage of GPP in Lithuania. To ground all these measures and tools, more accurate analysis of GPP, tender calls and actual purchase contracts, as well as the main objects and purchase areas, skills and needs of purchasing institutions would be beneficial and are open for further research.

\section{Conclusions}

1. Though legal preconditions for developing green public procurement are created in Lithuania, practical implementation of GPP is not smooth. In 2010 GPP accounted only to $5.8 \%$ of all performed public procurements in Lithuania.

2. Procuring institutions, which have to apply environmental criteria to their procurement, account $6.1 \%$ of GPP in their overall public procurements performed. Meanwhile the strategic foreseen goal in the National Program for Green Public Procurement Implementation is $25 \%$.

3. It is estimated that the biggest share of GPP value is allocated to purchased works. This procurement object amounted to $87 \%$ in 2008 , $76 \%$ in 2009 , and $82 \%$ in 2010 of all the value of GPP. Construction works composed the biggest share within the works group.

4. Applying up to three environmental criteria to three product groups (personal computers, laser printers, automobiles) for $50 \%$ of purchased products reduction of 75.5 tons of $\mathrm{CO}_{2}$ could have been achieved additionally in 2008 .

5. Acknowledging the importance of GPP and fostering its further development, it is necessary to improve information provision to all stakeholders, spread of the best practices, and creation of auxiliary instruments for procurement specialists, as well as political support and impose stricter commitments to purchasing institutions.

\section{References}

DE LEONARDIS F. 2011: Green Public Procurement: From Recommendation to Obligation. International Journal of Public Administration, 34:1-2, 110$113 \mathrm{http} / / / \mathrm{dx}$. doi.org/10.1080/01900692.2011.536093

COMMISSION OF THE EUROPEAN COMMUNITIES (CEC). 2008. Public procurement for a better environment. Communication from the Commission to the European Parliament, the Council, the European Economic and Social Committee and the Committee of the Regions (COM (2008) 400 final), Brussels.

EEA. 2008. Time for action - towards sustainable consumption and production in Europe. Summary report of the conference held on 27-29 September 2007, Ljubljana, Slovenia. EEA technical report No1/2008. 146 p.

EUROPEAN COMMISSION DG ENVIRONMENT WEBSITE.2011.URL:http://ec.europa.eu/environment/gpp/ index_en.htm [accessed 10th August 2011]

EVANS, L., NUTTALL, CHR., MOUAT, A., EWING, D. 2010. Assessment and Comparison of National GPP/SPP Criteria and Underlying Schemes. Report for DG Environment, European Commission prepared by AEA. 228 p. 
INTEGRALAUS ATLIKTU VIEŠUJU PIRKIMU POVEIKIO APLINKAI VERTINIMO STUDIJA [Study on integrated green public procurement environmental impact assessment]. 2008. UAB „NACIONALINIŲ PROJEKTŲ RENGIMAS“ Vilnius. $15 \mathrm{p}$.

MICHELSEN O., DE BOER L. 2009. Green procurement in Norway; a survey of practices at the municipal and county level. Journal of Environmental Management 9, 160-167 http://dx.doi.org/10.1016/j.jenvman.2009.08.001

NACIONALINĖ ŽALIŲJŲ PIRKIMŲ IGYVENDINIMO PROGRAMA. [National program for Green Public Procurement Implementation]. 2007. Lietuvos Respublikos Vyriausybè, 2007 m. rugpjūčio 8 d. nutarimas Nr. $804 \mathrm{p}$

NATIONAL STRATEGY FOR SUSTAINABLE DEVELOPMENT (NSSD). 2009. Approved by Resolution No 1160 of the Government of the Republic of Lithuania of 11 September 2003 (as amended by Resolution No 1247 of the Government of the Republic of Lithuania of 16 September 2009). 108 p.

NISSINEN A., PARIKKA-ALHOLA K., RITA H. 2009. Environmental criteria in the public purchases above the EU threshold values by three Nordic countries: 2003 and 2005. Ecological Economics, 68, 1838 - 1849 http://dx.doi.org/10.1016/j.ecolecon.2008.12.005
PRICEWATERHOUSECOOPERS， SIGNIFICANT AND ECOFYS. 2009. Collection of statistical information on Green Public Procurement in the EU. Report on data collection results, 110 p. URL: http://ec.europa.eu/environment/gpp/pdf/statistical informat ion.pdf [Online: accessed 10th August 2011]

VIEŠŲJŲ PIRKIMŲ İSTATYMAS [Law on Public Procurement]. 1996. Lietuvos Respublika, rugpjūčio 13 d. Nr. I-1491. Vilnius.

Dr. Renata Dagiliūtė - lecturer at Vytautas Magnus University, Department of Environmental Sciences, Lithuania.

Main research areas: sustainable production and consumption, eco-efficiency, sustainable development.

Address: $\quad$ Vileikos Str. 8, LT-44404, Kaunas,

Lithuania

Tel.:

+37037327904

E-mail: r.dagiliute@gmf.vdu.lt

Kristina Anikanova - Master's student at the department of Environmental Sciences, Vytautas Magnus University, Lithuania.

Main research areas: sustainable production and consumption, green public procurement.

Address: Vileikos Str. 8, LT-44404, Kaunas,

Lithuania

Tel.: $\quad+37037327904$

\title{
Žalieji viešieji pirkimai Lietuvoje: apimtys ir galimybės poveikio aplinkai mažinimui
}

\author{
Renata Dagiliūtė, Kristina Anikanova \\ Aplinkotyros katedra, Vytauto Didžiojo universitetas
}

(gauta 2011 m. rugsèjo mèn.; atiduota spaudai 2011 m. gruodžio mèn.)

Žaliasis viešasis pirkimas - tai toks pirkimas, kuris įtraukia aplinkosauginius aspektus ị viešaji pirkimą ir padeda siekti poveikio aplinkai mažinimo tikslų. Šio straipsnio tikslas išanalizuoti žaliujų viešujų pirkimų eigą 2008 - 2010 Lietuvoje, jų apimtis ir galimybes poveikio aplinkai mažinimui.

Nustatyta, kad žaliujų viešujų pirkimų igyvendinimas Lietuvoje nėa sklandus ir atsilieka nuo nustatytų tikslų. $2008 \mathrm{~m}$. žalieji viešieji prikimai sudare 8,3\%, $2009 \mathrm{~m}$. - 6,1\%, $2010 \mathrm{~m}$. - 5,8\% viešujjų pirkimų. Didžioji dalis žaliujų viešujų pirkimų buvo taikyta ịvairiems darbams $(82 \%)$, daugiausia susijusiems su statybomis. Tačiau visos galimybès poveikio aplinkai sumažinimui $\left(\mathrm{CO}_{2}\right)$ nèra išnaudotos. Lyginant su pasiekta nauda, nustatyta, kad buvo galima sutaupyti 126 150 tonu $\mathrm{CO}_{2}$, taikant aplinkosauginius kriterijus bent $50 \%$ visų atliktu pirkimų trijose produktų grupėse. Taigi svarbu spartinti žaliuosius pirkimus Lietuvoje, siekiant ne tik mažinti poveiki aplinkai, bet ir kurti aplinkai palankių prekių ir paslaugų rinką. 